\title{
Critical review of the equations predicting 6-minute walking distance in obese subjects
}

\author{
Lorenzo Maria Donini1, Eleonora Poggiogalle1, Veronica Mosca1, Alessandro Pinto1, \\ Silvia Migliaccio², Amelia Brunani33, Paolo Capodaglio3
}

1 Department of Experimental Medicine - Medical Physiopathology, Food Science and Endocrinology Section, Sapienza University of Rome

2 Department of Movement, Human and Health Sciences, Unit of Endocrinology University Foro Italico

of Rome

3 Rehabilitation Unit, S. Giuseppe Hospital, Istituto Auxologico Italiano IRCCS, Piancavallo, Italy

\section{Abstract}

The correlation between the 6 -minute walking distance and obesity has been only partially explored. Results obtained from the existing predictive equations are influenced by a variety of factors (health status, severity of obesity, reduced muscle strength and mobility, decreased aerobic capacity, presence of comorbidities).

The aim of our study was to verify, compare and discuss the 6MWD predictive capacity of the equations currently available in the literature in a sample of obese subjects.

Despite similar study design, the considered articles varied with regard to the number of individuals included and to age range. None of the equations available in the literature was able to accurately predict the six-minute walked distance performed by the obese subjects involved in our study. The six-minute walked distance performed by obese subjects seems to be influenced by other factors than the variables included in the equations from the literature, suggesting that they may not thoroughly capture the complexity of disability in obese people. Future research should be designed in order to validate population-specific equations, by including variables related to clinical, functional, and psychological areas, which are usually impaired in obese individuals.

Corresponding author: Lorenzo M. Donini, "Sapienza" University of Rome, Department of Experimental Medicine, P.le Aldo Moro 5, 00185 Rome, Italy. Tel.: +39.06.4969.0216 - Fax: +39.06.4991.0699.

E-mail: lorenzomaria.donini@uniromal.it

Key words: Obesity; disability; 6-minute walking test.

Received for publication: 27 February 2014

Accepted for publication: 15 May 2014

CC Copyright L.M. Donini et al., 2015

Tipografia PI-ME Editrice, Italy

Monaldi Archives for Chest Disease Pulmonary Series 2015; 81:745

doi: 10.4081/monaldi.2015.745

This article is distributed under the terms of the Creative Commons Attribution Noncommercial License (by-nc 4.0) which permits any noncommercial use, distribution, and reproduction in any medium, provided the original author(s) and source are credited.

\section{Introduction}

Obesity (generally defined by body mass index (BMI) $\geq 30 \mathrm{~kg} / \mathrm{m}^{2}$ ) is a chronic disease due to complex pathogenesis, and it is characterized by a significantly increased comorbidity and severe consequences affecting the quality of life and overall disability [1]. The risk of disability is significantly higher in obese subjects: obesity impairs the interaction between the individual and the environment, reduces independence in activities of the daily living and participation in social life [1]. It is known that: difficulty in activities of the daily living (ADLs) increases progressively with the degree of obesity [2]; fat mass, in particular the abdominal fat mass, is inversely related to physical performance and motor function, especially if associated to the decrease of the lean mass (the so-called sarcopenia) [3,4]; the increase of waist circumference and waist-to-hip ratio is positively associated to functional limitations and disability in the ADLs as well as in the instrumental activities of daily living (IADLs) [5].

Another factor responsible for disability is the impaired respiratory function linked to obesity. In fact, the increased fat accumulation might impair the thorax mechanic efficiency in obese people, leading to alter respiratory conditions, which, in a vicious circle, worsen the functional impairment [6]. In obese subjects, the metabolic cost and the oxygen consumption are higher, pulmonary volumes are reduced with increased ventilation and respiratory muscles are under greater strain. Indeed, dyspnea occurs frequently in obese subjects and the expiratory flow is reduced even in absence of bronchial obstruction [7]. Moreover, obesity is strictly linked to respiratory disorders during sleep, such as the Sleep Apnea Syndrome, characterized by a repeated total or partial (hypopnea) collapse of the upper airway, inducing an irregular respiratory rhythm during sleep with intermittent transitory hypoxia $[8,9]$.

In the onset of the obesity-related disability, functions linked to the lower limbs (strength and balance capacity) appear to be more susceptible than those associated to the upper limbs (strength and dexterity) [10-12]. Exercise capacity is a strong predictor of disability as well as morbidity in the general population: physical functioning and exercise capacity are associated with improved quality of life and survival $[13,14]$. No test performed under resting condition is able to predict the cardiac and respiratory functions, and symptoms linked to physical activity, especially dyspnea, are weakly correlated with cardio-pulmonary function evaluations when performed at rest. Physical exercise, involving different organs and systems such as heart, lungs and muscles, allows a more complete evaluation of the functional reserve [15-17]. Individual exercise capacity can be assessed only by means of a standardized reproducible physical effort. Walking capacity (i.e. 
walking a certain distance) represents a rapid and cost-saving measurement of the functional reserve and of quality of life, reflecting the ability to perform the activities of daily living [18]. The 6-minute walking test (6MWT) is an easy to administer, inexpensive and safe tool to assess cardiovascular fitness, and its results are highly correlated with other cardiovascular and respiratory functional tests (e.g. Sit-to-stand test, V02max and maximum work capacity) [19]. Walking, rather than cycling, has also the advantage to be more reflective of the subject's habitual activities [20].

Many authors have previously studied the factors influencing the 6minute walking distance in healthy adults and several predictive equations have been developed [21,22]. After the publication of the official guidelines for the 6MWT elaborated by the American Thoracic Society in 2002 [23], several studies have been carried out aiming at the development of predictive equations of the 6MWT in different population groups, taking into account ethnicity and specific conditions. Prediction equations allow the comparison of the performance with subjects matched for age, gender and clinical status. Comparison to normative data can be useful to assess functional capacity, plan exercise intensity, monitor changes over time and interpret results of the interventions [24-27].

Few studies have explored the performance during the 6MWT in obese subjects [28-31]. Despite high reproducibility, results from these studies are influenced by a wealth of factors, including health status, severity of obesity, reduced muscle strength and mobility, decreased aerobic capacity and presence of comorbidities, with special regard to pulmonary and cardiovascular diseases. According to the predictive equations from the literature, obese subjects consistently show a deficit in distance walked and in work exerted for walking when compared with normal-weight subjects. Reference values obtained from healthy, normal-weight populations therefore predictably underline the reduced performance capacity of obese individuals. Instead, reference values specific for this population would serve as benchmark to assess baseline functional capacity, prescribe proper and safe exercise intensity and monitor changes after rehabilitation interventions.

The aim of our study was therefore to verify, compare and discuss the predictive capacity of the equations currently available in the literature in a sample of obese subjects actually performing the 6MWT.

\section{Materials and methods}

\section{Identification of prediction equations for the six-minute walked distance in the literature}

Relevant studies were identified in PubMed run by the NCBI of the National Library of Medicine of Bethesda (USA), through selection of key-words such as $6 M W T$, reference equation, prediction, obesity that define the interest field of the documents to search, grouped in inverted commas ("...") and used separately or in combination. The boolean $A N D$ operator to allow logical relations among concepts and research modalities such as advanced search were used.

The considered limitations were papers on human subjects, aged $>18$ years, written in English, French or Italian. No limits were imposed as for the year range of the literature review.

The results of the selected papers were presented and compared with a particular reference to the first author, the name of the journal where the study was published, year of publication, study characteristics, selection criteria, subjects included, validation procedures, presence of subjects with a BMI $\geq 30 \mathrm{~kg} / \mathrm{m}^{2}$.

We selected the predictive equations to be applied to the experimental sample performing the 6MWT among the formulas validated in the Italian population and/or used in samples of obese subjects.

\section{Comparison of the results obtained applying different equations from the literature to the experimental sample}

Obese patients (BMI $\geq 30 \mathrm{~kg} / \mathrm{m}^{2}$ ) were recruited in the rehabilitation facility at the Department of Experimental Medicine, Medical Physiopatology, Food Science and Endocrinology Section from January 2009 to December 2011. They represent all the obese patients hospitalized in the facility during the survey period.

The exclusion criteria included: age $<18$ years or $>80$ years; bedridden subjects; clinical conditions (unstable angina, myocardial infarction in the previous month, uncontrolled hypertension with blood pressure values exceeding $180 / 100 \mathrm{mmHg}$ ) contraindicating the 6MWT performance and those who have had to stop the test as required by the Guidelines (chest pain, intolerable dyspnea, leg cramps, staggering, excessive sweating, etc.) [23].

All the recruited subject underwent the following evaluations and measurements: i) anthropometric measurements, following the procedures described in the Anthropometric standardisation reference manual by Lohman et al. [32], performed by a skilled operator. Body weight was measured to the nearest $0.1 \mathrm{~kg}$ through a standard column body scale (SECA, Hamburg, Germany). Body height (using a rigid stadiometer SECA, Hamburg, Germany), waist (W) and arm circumferences (AC) (using a measuring tape) were determined to the nearest $0.1 \mathrm{~cm}$. ii) 6MWT, following the guidelines by the American Thoracic Society [23]. In particular, suggested safety rules, as well as the criteria for immediate stopping the test (chest pain, intolerable dyspnea, leg cramps, staggering, diaphoresis, pale or ashen appearance) were respected. The day before the test, an exhaustive explanation of the procedures, including where the test would take place, was provided to the patients. The 6MWT was performed in an undisturbed 20-meter hospital corridor marked every 2 meters with colored tape on the floor. Before the test, the subject's pulse, respiratory rate, peripheral capillary oxygen saturation $\left(\mathrm{SpO}_{2}\right)$ and blood pressure were measured. At 1-, 3- and 5-minute during the test, the subject's pulse and $\mathrm{SpO}_{2}$ were verified using a portable pulse oxymeter. At test completion, the subject's pulse, respiratory rate, $\mathrm{SpO}_{2}$, blood pressure and perceived fatigue on Borg's scale were measured [33]. Subjects were instructed to walk as far as possible for 6 minutes and received standardized encouragements [23]. They were allowed to stop or rest during the test if necessary. The distance walked in 6 minutes was computed.

The results calculated from those equations were compared with the distances actually walked by the subjects in our study sample.

From the distance walked during the 6MWT and the body weight of the subjects the workload was calculated as (body weight * walked distance) [31].

\section{Data analysis and statistics}

The study protocol was approved by the Ethical Committee of the Sapienza University of Rome and all the subjects gave their oral and written informed consent to the anonymous use of personal data.

A $t$-test was performed to describe differences between means (walked vs predicted distance at the 6MWT). Differences were considered to be statistically significant for $\mathrm{p}<0.05$. Statistical analysis was performed using SPSS 10.0 statistical software (SPSS Inc Wacker Drive, Chicago, IL, USA).

\section{Results}

\section{Identification of the prediction equations of the six-minute walked distance in the literature}

From the literature, 14 equations for the estimation of the distance walked at the $6 \mathrm{MWT}$ were selected. The main characteristics of the 
studies are reported in Table 1. In particular, two equations [29,31] had been specifically developed for obese subjects, while in other eight studies [18,26,35-40] both obese (BMI $\geq 30 \mathrm{~kg} / \mathrm{m}^{2}$ ) and non-obese subjects were enrolled. In four papers $[20,25,34,41]$ no information was available with respect to the presence or absence of obese subjects in the study sample. Only four studies [18,34,35,37] used a randomized selection of the subjects. The most used exclusion criteria were smoking (8 studies), cardiovascular, respiratory and chronic diseases

Table 1. Description of studies that validated an equation predicting the distance walked at the 6MWT.

\begin{tabular}{|c|c|c|c|c|}
\hline \multirow[t]{2}{*}{ Study } & \multicolumn{2}{|c|}{ Study sample } & \multirow[t]{2}{*}{ Exclusion criteria } & \multirow[t]{2}{*}{ Presence of obese subjects } \\
\hline & Selection & Participants & & \\
\hline Alameri H et al. [35] & Randomized & $\begin{array}{l}127 \mathrm{M}, 111 \mathrm{~F}, \\
\text { from Saudi Arabia, } \\
\text { aged } 18-50 \text { years }\end{array}$ & $\begin{array}{l}\text { Smokers (current or ex), cardiopulmonary } \\
\text { and respiratory diseases }\end{array}$ & $\mathrm{BMI} \leq 35 \mathrm{~kg} / \mathrm{m}^{2}$ \\
\hline Ben Saad H et al. [36] & & $\begin{array}{l}104 \mathrm{M}, 125 \mathrm{~F}, \\
\text { from Tunisia, } \\
\text { aged } \geq 40 \text { years }\end{array}$ & $\begin{array}{l}\text { Smokers, morbid obesity or low weight, } \\
\text { cardiopulmonary, metabolic or orthopedic diseases, } \\
\text { those undergoing chronic drug therapy }\end{array}$ & $\begin{array}{l}55.9 \% \text { overweight } \\
\left.\text { (BMI } 25-29.9 \mathrm{~kg} / \mathrm{m}^{2}\right) \\
\text { and } 24 \% \text { obese } \\
\left(\mathrm{BMI} \geq 30 \mathrm{~kg} / \mathrm{m}^{2}\right)\end{array}$ \\
\hline Camarri B et al. [37] & Randomized & $\begin{array}{l}33 \mathrm{M}, 37 \mathrm{~F} \text {, healthy, } \\
\text { from Australia, } \\
\text { aged } 55-75 \text { years }\end{array}$ & $\begin{array}{l}\text { Smokers, respiratory diseases and medications } \\
\text { that could affect the exercise capacity, } \\
\text { diabetes mellitus, use of gait-aid ortheses, } \\
\text { neuromuscular and osteoarticular diseases }\end{array}$ & $\begin{array}{l}\text { 47.1\% overweight } \\
\left(\text { BMI } 25-29.9 \mathrm{~kg} / \mathrm{m}^{2}\right) \\
\text { and } 15.7 \% \text { obese } \\
\left(\mathrm{BMI} \geq 30 \mathrm{~kg} / \mathrm{m}^{2}\right)\end{array}$ \\
\hline Capodaglio P et al. [29] & & $\begin{array}{l}141 \mathrm{~F}, 86 \mathrm{M} \text {, } \\
\text { obese subjects, } \\
\text { from Italy, } \\
\text { aged } 20-60 \text { years }\end{array}$ & $\begin{array}{l}\text { Cardiovascular and respiratory contraindications, } \\
\text { neuromuscular and osteoarticular diseases } \\
\text { that could cause gait abnormality }\end{array}$ & $\begin{array}{l}\text { All patients had } \\
\text { a BMI } \geq 30 \mathrm{~kg} / \mathrm{m}^{2}\end{array}$ \\
\hline Casanova C et al. [40] & & $\begin{array}{l}238 \mathrm{M}, 206 \mathrm{~F}, \\
\text { from Central \& South } \\
\text { America and USA, } \\
\text { aged 40-80 years }\end{array}$ & $\begin{array}{l}\text { No history of chronic disease that could } \\
\text { influence their exercise capacity; } \\
\text { active but not involved in any competitive sport }\end{array}$ & $\begin{array}{c}19 \% \text { obese } \\
\left(\mathrm{BMI} \geq 30 \mathrm{~kg} / \mathrm{m}^{2}\right)\end{array}$ \\
\hline Chetta A et al. [34] & Randomized & $\begin{array}{l}48 \mathrm{M} \text { and } 54 \mathrm{~F} \text {, healthy, } \\
\text { from Italy, } \\
\text { aged } 20-50 \text { years }\end{array}$ & $\begin{array}{l}\text { Participation in sports activities, smokers, capable } \\
\text { history of hospitalization or chronic diseases } \\
\text { of affecting the capacity to perform exercises }\end{array}$ & Not indicated \\
\hline $\begin{array}{l}\text { Enright PL } \\
\& \text { Sherrill DL [18] }\end{array}$ & Randomized & $\begin{array}{l}117 \mathrm{M} \text { and } 173 \mathrm{~F}, \\
\text { from the USA, } \\
\text { aged } \geq 40 \text { years }\end{array}$ & $\begin{array}{l}\text { Age }>80 \text { years, smokers, presence of peripheral } \\
\text { vascular disease, history of cerebrovascular } \\
\text { accident, use of diuretics, abnormal spirometry }\end{array}$ & $\mathrm{BMI} \leq 35 \mathrm{~kg} / \mathrm{m}^{2}$ \\
\hline Enright PL et al. [20] & & $\begin{array}{l}437 \mathrm{~F}, 315 \mathrm{M} \text {, healthy, } \\
\text { from the USA, } \\
\text { aged } \geq 68 \text { years }\end{array}$ & $\begin{array}{l}\text { Regular use of gait-aid ortheses, musculoskeletal } \\
\text { problems, resting } \mathrm{SpO}_{2}<90.0 \% \text {, cardiovascular } \\
\text { accidents in the previous three months }\end{array}$ & Not indicated \\
\hline Gibbons WJ et al. [25] & & $\begin{array}{l}41 \mathrm{M}, 38 \mathrm{~F} \text {, healthy, } \\
\text { from the USA, } \\
\text { aged } 20-80 \text { years }\end{array}$ & $\begin{array}{l}\text { Smokers; history of pulmonary diseases, } \\
\text { cardiovascular disease, neuromuscular diseases, } \\
\text { arthritis, diabetes mellitus, cancer, use of medications }\end{array}$ & Not indicated \\
\hline Iwama AM et al. [38] & & $\begin{array}{l}134 \text { individuals, } \\
\text { from Brazil, } \\
\text { aged } \geq 13 \text { years }\end{array}$ & $\begin{array}{l}\text { Cardiovascular and/or pulmonary diseases, disorders } \\
\text { capable of interfering with the capacity of walking, } \\
\text { use of medications for chronic diseases }\end{array}$ & $\begin{array}{l}37.6 \% \text { overweight } \\
\left(\text { BMI } 25-29.9 \mathrm{~kg} / \mathrm{m}^{2}\right) \\
\text { and } 12.5 \% \text { obese } \\
\left(\mathrm{BMI} \geq 30 \mathrm{~kg} / \mathrm{m}^{2}\right)\end{array}$ \\
\hline LarssonUE et al. [31] & & $\begin{array}{l}16 \mathrm{M}, 27 \mathrm{~F} \text {, obese subjects, } \\
\text { from Sweden, } \\
\text { mean age } 47 \text { (21-62) years }\end{array}$ & $\begin{array}{l}\text { Known severe psychiatric diagnoses, } \\
\text { difficulty in understanding Swedish, } \\
\text { walking aids or total hip replacements }\end{array}$ & $\begin{array}{l}\text { All patients had } \\
\text { a BMI } \geq 30 \mathrm{~kg} / \mathrm{m}^{2}\end{array}$ \\
\hline Masmoudi Ket al. [41] & & $\begin{array}{c}80 \mathrm{M}, 75 \mathrm{~F}, \\
\text { from Tunisia, } \\
\text { aged } 40-80 \text { years }\end{array}$ & $\begin{array}{l}\text { Active individuals, smokers, } \\
\text { any chronic disease }\end{array}$ & Not indicated \\
\hline Poh H et al. [39] & & $\begin{array}{l}35 \text { individuals, } \\
\text { from Singapore, } \\
\text { aged } 45-85 \text { years }\end{array}$ & $\begin{array}{c}\text { Smokers, cardiovascular and respiratory disease, } \\
\text { metabolic disorders, difference in lower-limb length, } \\
\text { need to use gait-aid ortheses, } \\
\text { musculoskeletal pain or disability }\end{array}$ & $\begin{array}{c}17.1 \% \text { obese } \\
\left(\mathrm{BMI} \geq 27 \mathrm{~kg} / \mathrm{m}^{2}\right)\end{array}$ \\
\hline Troosters T et al. [26] & & $\begin{array}{l}53 \text { healthy individuals, } \\
\text { from Belgium, } \\
\text { aged } 50-85 \text { years }\end{array}$ & $\begin{array}{l}\text { Participation in sports activities, } \\
\text { history of hospitalizations or diseases } \\
\text { capable of affecting the walking capacity }\end{array}$ & $\mathrm{BMI} \leq 35 \mathrm{~kg} / \mathrm{m}^{2}$ \\
\hline
\end{tabular}

Legend: 6MWT: six minute walk test; BMI: body mass index. 
(11 studies), use of medications that could affect the exercise capacity (3 studies), use of walking aids or ortheses (4 studies), neuromuscular and ostheoarticular diseases (6 studies).

Figure 1 describes the selection procedure [42] while Table 2 summarizes the variables included in the selected equations predicting the distance walked during the 6MWT and the validity of the proposed models through $\mathrm{R}^{2}$ values.

Predictive equations applied to the experimental sample performing the 6MWT were the followings:

1. $6 \mathrm{MWD}=894.2177-[2.07 \mathrm{x}$ age(years) $]-[51.4489 \mathrm{x}$ gender $(1=\mathrm{fe}-$ male) $]$ - [5.1663* BMI] (Capodaglio et al. [29])

2. $6 \mathrm{MWD}=\left[7.57^{*}\right.$ height $\left.(\mathrm{cm})\right]-\left[5.02^{*}\right.$ age (years) $]-\left[1.76^{*}\right.$ weight $\left.(\mathrm{kg})\right]$ -309 for men (Enright et al. [18])

3. $6 \mathrm{MWD}=1140-\left[5.61^{*} \mathrm{BMI}\right]-\left[6.94^{*}\right.$ age(years) $]$ for men (Enright et al. [18])

4. $6 \mathrm{MWD}=[2.11 *$ height $(\mathrm{cm})]-[2.29 *$ age (years) $]-\left[5.78^{*}\right.$ weight $\left.(\mathrm{kg})\right]$ +667 for women (Enright et al. [18])

5. $\quad 6 \mathrm{MWD}=1017-\left(6.24^{*} \mathrm{BMI}\right)-\left[5.83^{*}\right.$ age (years) $]$ for women (Enright et al. [18])

6. $6 \mathrm{MWD}=518.853+\left[1.25^{*}\right.$ height $\left.(\mathrm{cm})\right]-[2.816 \mathrm{x}$ age $($ years $)]-$ [39.07* gender( 1 =female)] (Chetta et al. [34])

The selection of the equations was based on the following considerations: i) the equations by Enright et al. [18], although not very recent, were selected because they have been considered as the reference equations for the 6MWT in many papers; ii) the equation by Chetta $e t$ al. [34] has been chosen because it has been validated in the Italian population; iii) the equation by Capodaglio et al. [29] was included because, besides having been validated in the Italian population, considers a large sample of obese subjects (the only other equation validated in obese individuals [31] was developed using a sample of 43 subjects).

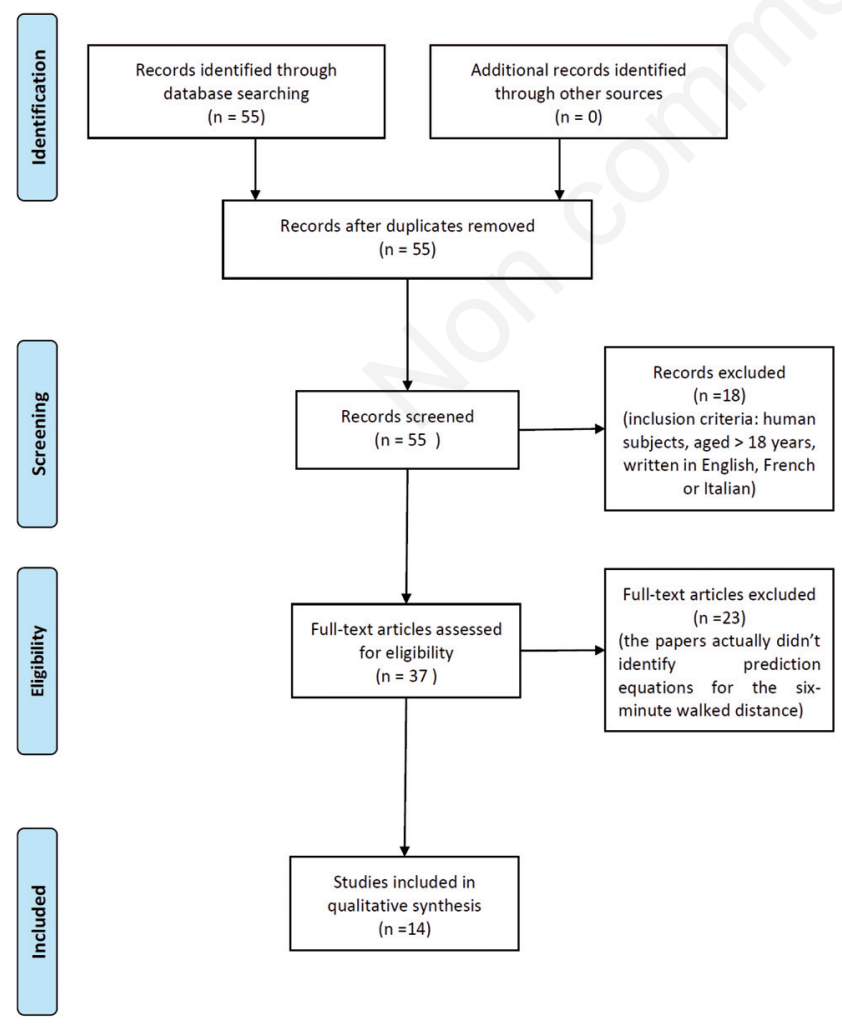

Figure 1. PRISMA 2009 Flow Diagram (Moher D et al. [42]).

\section{Comparison of the prediction capacity of the equations in our population sample}

We enrolled 295 subjects (74 men, mean age $47.1 \pm 13$ years, and 221 women, mean age $48.3 \pm 15$ years). All the participants showed a BMI $\geq 30 \mathrm{~kg} / \mathrm{m}^{2}\left(44.0 \pm 7 \mathrm{~kg} / \mathrm{m}^{2}\right.$ in men and $42.4 \pm 7 \mathrm{~kg} / \mathrm{m}^{2}$ in women, respectively). Statistically significant differences $(\mathrm{p}<0.05)$ emerged between males and females especially with regard to the distance walked during the 6MWT $(448.5 \pm 107 \mathrm{~m}$ in men versus $422.8 \pm 82 \mathrm{~m}$ in women, respectively). Calculated workloads (body weight ${ }^{*}$ walked distance) were $57901.0 \pm 7250$ vs. $44774.5 \pm 6873 \mathrm{~kg} . \mathrm{m}$ for men and women, respectively $(\mathrm{p}<0.05)$ and globally $47955.3 \pm 7145 \mathrm{~kg} . \mathrm{m}$ for the entire sample.

The results concerning the reliability of predictive models from the literature are shown in Table 3. In particular, the difference between walked and predicted distance varied from 81.5 to $153.2 \mathrm{~m}$ for males and from 52.4 to $119.5 \mathrm{~m}$ for females. None of the equations was able to predict with accuracy the distance walked at the 6MWT (both for the whole sample or according to gender), although the correlations between the predicted and walked distances resulted significant $(\mathrm{p}<0.05)$ for all of the equations. The calculated workloads were also different in the studies considered (Figure 2).

Table 4 depicts the procedures adopted and the samples selected in different validation studies on the 6MWT.

\section{Discussion}

In the literature we found 14 different reference equations for predicting the distance walked during the 6MWT. Despite similar study design, the considered articles varied with regard to the number of individuals enrolled and their age range. In most studies, the reference equations were obtained by using linear multiple regression models, including demographic and anthropometric features as independent variables.

The equations that we selected in the existing literature (Enright $e t$ al. [18], Capodaglio et al. [29] and Chetta et al. [34]) do not appear to reliably predict the distance walked during the 6MWT when applied to obese subjects. According to the data obtained in our study, significant differences emerged between the distance walked by obese individuals in our sample and the distance estimated using the equations above mentioned.

A possible explanation for the discrepancies we found may be due to the differences in the populations used in the studies and examined for the validation of the equations. Enright et al. [18] and Chetta et al. [35] enrolled healthy subjects with only a low proportion of obese subjects. Moreover, distances walked in these studies were higher than in our sample, even at a lower workload. Our data are consistent with the results of a study by Hulens et al. [30] (despite differences in the study design regarding the control group) showing that the distance walked during the 6MWT was shorter in obese $(131.0 \mathrm{~m})$ and even shorter in morbidly obese women $(183.4 \mathrm{~m})$ than the distance walked by lean controls. Indeed, obese participants walked $81.9 \%$ and morbidly obese only $64.6 \%$ of the distance lean women were able to walk. Despite similar study sample characteristics and methods [23] (Italian subjects admitted to a Rehabilitation Unit devoted to the management of functional and clinical complications of obesity, with similar BMI and gender distribution), our results are not consistent with those provided by Capodaglio et al. [29]. Discrepancies might be due to the higher mean age in our study (10 years higher), the lower track length $(20 \mathrm{~m}$ in our study versus $30 \mathrm{~m}$ ), as well as the lower workload in our study. There is some evidence that track length does not appear to significantly influence the distance walked during 6MWT [43]. On the contrary, age (in particular age $>60$ years) may be considered one of the most important factors influencing the distance walked during the 
Table 2. Variables included in the equations predicting the distance walked at the 6MWT and validity of the proposed models.

\begin{tabular}{|c|c|c|}
\hline Study & Variables included in the equation & $\mathbf{R}^{2}$ \\
\hline Alameri H et al. [35] & Age, Height & 0.25 \\
\hline Ben Saad H et al. [36] & Gender, age, weight, height & 0.77 \\
\hline Camarri B et al. [37] & Gender, age, weight, height & 0.36 \\
\hline Capodaglio P et al. [29] & Gender, age, BMI & 0.48 \\
\hline Casanova C et al. [40] & Age, height, weight, HR & 0,38 \\
\hline Chetta A et al. [34] & Gender, age, height & 0.42 \\
\hline Enright PL \& Sherrill DL [18] & Gender, age, weight, height (or BMI) & $0.42 \mathrm{M}, 0.38 \mathrm{~F}$ \\
\hline Enright PL et al. [20] & Gender, age, weight, height & 0.20 \\
\hline Gibbons WJ et al. [25] & Gender, age & 0.41 \\
\hline Iwama AM et al. [38] & Gender, age & 0.30 \\
\hline LarssonUE et al. [31] & Gender, height, BMI, final HR, HR at rest, & 0,71 \\
\hline Masmoudi K et al. [41] & Gender, age, weight, height & 0.60 \\
\hline Poh Het al. [39] & Age, weight, height, hearth rate & 0.78 \\
\hline Troosters T et al. [26] & Gender, age, weight, height & 0.66 \\
\hline
\end{tabular}

Legend: 6MWT: six minute walk test; HR: heart rate; BMI: body mass index.

Table 3. Walked and predicted distance for 6MWT.

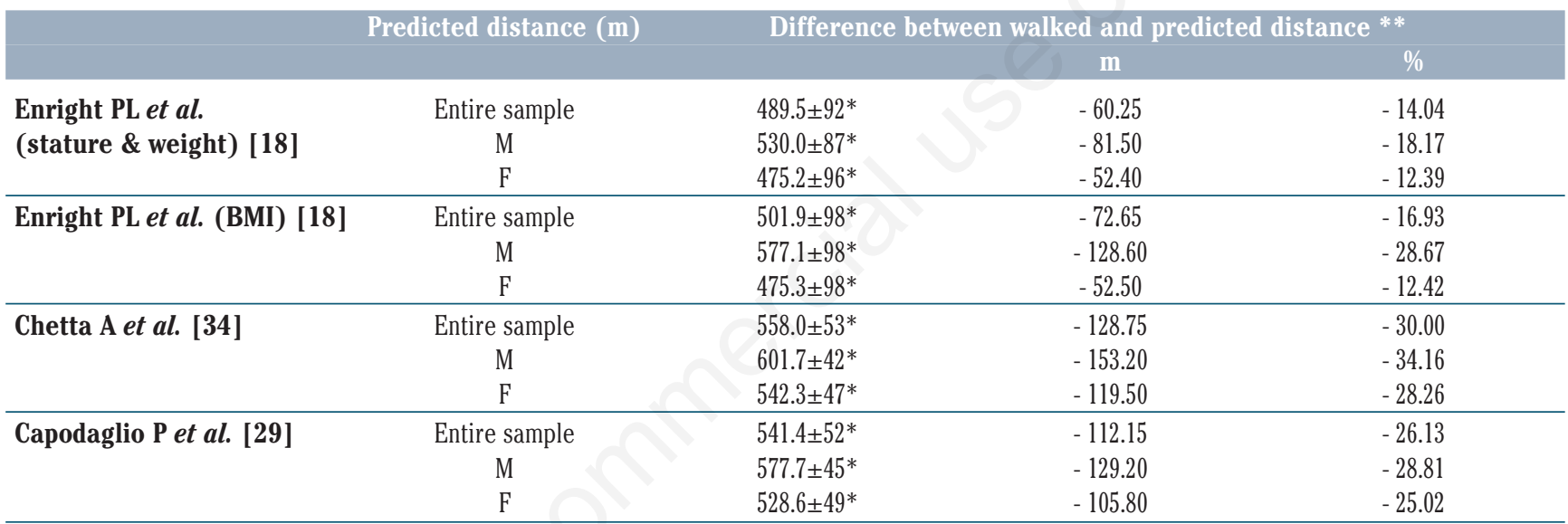

${ }^{*} \mathrm{p}<0.05$ considering the difference between real and predicted distance (t-test); ${ }^{* *}$ Real walked distance (m): entire sample: 429.25 $\pm 91 ;$ M: 448.5 $\pm 107 ; \mathrm{F}: 422.8 \pm 82$.

Legend: 6MWT: 6 minute walk test.

6MWT [25]. In fact, age represents a proxy of disability, which evidently affects the performance during the 6MWT. In our sample $20 \%$ of subjects were over 60 years and $3 \%$ were 70 years old, whereas in the paper by Capodaglio et al. [29] age ranged from 20 to 60 years. Even if age was taken into account as explanatory variable by those Authors [29], the equation was validated in a sample whose age was below 60 years, thus reducing the predictive validity for elderly subjects.

Two studies suggest that 6MWT seems to be highly reproducible and reliable in overweight and obese individuals [28,31] and that it could be used to quantify some aspects of the functional capacity of obese patients and to monitor changes in fitness over the course of weight management interventions. Obesity increases the work load for a given amount of exercise, probably resulting in the shorter distances walked by women with a higher body weight or BMI; moreover, both body weight and BMI were significant when entered into the models $[18,20]$. Other studies reported [25,28,30,37] significant correlations between the distance walked during 6MWT and height, body weight, and BMI. On the contrary, Poh et al. [39] failed to show an inverse relationship between BMI and the distance at the 6MWT. In another study [35], BMI was more linearly associated with the distance at the 6MWT in females than in males. Women with a BMI $>25 \mathrm{~kg} / \mathrm{m}^{2}$ walked shorter distances, while a positive correlation was observed between distance walked and women with BMI $<25 \mathrm{~kg} / \mathrm{m}^{2}$.

In consideration of the data mentioned above, BMI does not seem to thoroughly describe function in obesity, and therefore other variables with reference to the clinical and functional status should be taken into account. Variables used in the existent literature may not thoroughly capture the complexity of disability in obese people. In fact, obese individuals, in association with the increased BMI, show an energetic, cardiac and respiratory, limitation leading to a mobility impairment $[45,46]$, together with the relative reduction of skeletal muscle strength and general deconditioning, also leading to disability $[47,48]$. Other potential contributors to the disabling status of obese subjects are the friction of the skin through fat depositions on the thighs, the increased plantar foot pressure (first and lesser metatarsal, mid-foot and heel region), as well as the pain and discomfort experienced when performing physical activities [30,49-51].

Investigating the difference in walking capacity between obese and non-obese women, Hulens et al. [30] found that $59 \%$ of the variance could be explained by BMI but other important variables, such as peak aerobic capacity, knee extension torque, age and hours of TV viewing, resulted to play an important role in determining walking capacity of obese subjects. 


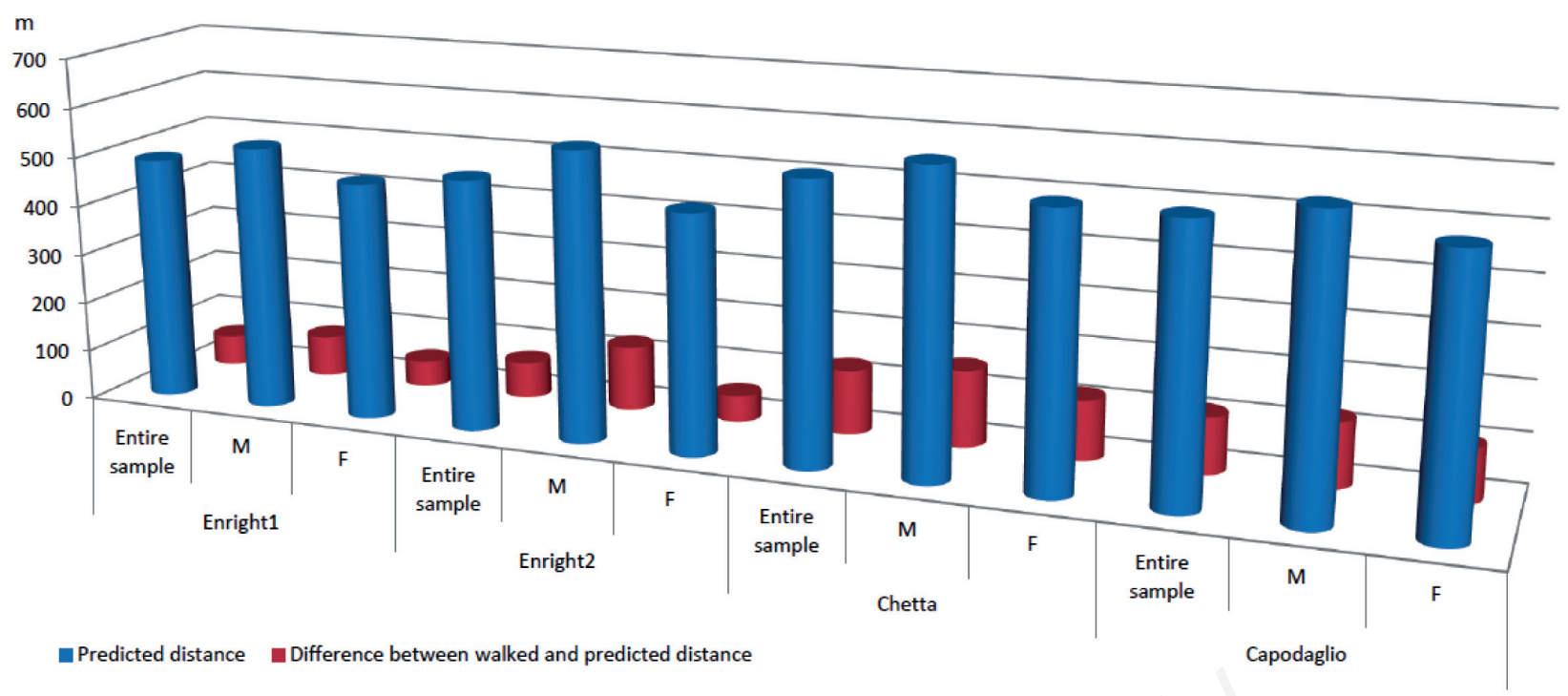

Legend: Enright1: $6 \mathrm{MWD}=[7.57 *$ height $(\mathrm{cm})]-[5.02 *$ age $($ years $)]-[1.76 *$ weight $(\mathrm{kg})]-309$ for men and $=[2.11 *$ height $(\mathrm{cm})]-[2.29 *$ age $($ years $)]-$ $\left[5.78^{*}\right.$ weight $\left.(\mathrm{kg})\right]+667$ for women. $[18]$; Enright2: $6 \mathrm{MWD}=1140-\left[5.61^{*} \mathrm{BMI}\right]-\left[6.94^{*}\right.$ age(years)] for men and $=1017-\left(6.24^{*} \mathrm{BMI}\right)-\left[5.83^{*}\right.$ age $($ years $\left.)\right]$ for women [18]; Chetta: $6 \mathrm{MWD}=518.853+[1.25 *$ height $(\mathrm{cm})]-[2.816 \mathrm{x}$ age(years)] $-[39.07 *$ gender(1=female)] [34]; Capodaglio: 6MWD = 894.2177 $-[2.07 \mathrm{x}$ age(years)] - [51.4489 x gender(1=female)] - [5.1663* BMI] [29]; 6MWD: six-minute walked distance; BMI: body mass index.

Figure 2. Walked and predicted distance for 6MWT.

Table 4. Comparison of the procedures adopted and the samples selected in different validation studies on the 6MWT.

\begin{tabular}{|c|c|c|c|c|}
\hline & Enright PL et al. [18] & Chetta A et al. [34] & Capodaglio P et al. [29] & Present study \\
\hline $\begin{array}{l}\text { Standardization } \\
\text { used in the test }\end{array}$ & $\begin{array}{c}\text { Butland RJA et al., } \\
1982\end{array}$ & $\begin{array}{c}\text { ATS STATEMENT, } \\
2002 \\
\end{array}$ & $\begin{array}{c}\text { ATS STATEMENT, } \\
2002 \\
\end{array}$ & $\begin{array}{c}\text { ATS STATEMENT, } \\
2002 \\
\end{array}$ \\
\hline Track length & $100 \mathrm{ft}$ & $30 \mathrm{~m}$ & $30 \mathrm{~m}$ & $20 \mathrm{~m}$ \\
\hline Practice test & NO & One test $60 \mathrm{~m}$ before & Not indicated & NO \\
\hline $\begin{array}{l}\text { Ethnic-population } \\
\text { characteristics }\end{array}$ & $\begin{array}{c}\text { Not indicated } \\
\text { (stratified cluster of } \\
\text { persons in Tucson-AR-USA) }\end{array}$ & $\begin{array}{c}\text { Not indicated } \\
\text { (selection in University } \\
\text { Campus and surrounding } \\
\text { community in Italy) }\end{array}$ & $\begin{array}{c}\text { Not indicated } \\
\text { (selection in Rehabilitation } \\
\text { Unit in Italy) }\end{array}$ & Caucasian (Italian) \\
\hline $\mathrm{N}$ & $\begin{array}{l}117 \\
173 \\
\end{array}$ & $\begin{array}{l}48 \\
54 \\
\end{array}$ & $\begin{array}{c}86 \\
141 \\
\end{array}$ & $\begin{array}{r}74 \\
221\end{array}$ \\
\hline Age (years) & $\begin{array}{l}59.5(43-77) \\
62.0(45-79) \\
\end{array}$ & $\begin{array}{l}36 \pm 8 \\
33 \pm 9\end{array}$ & $35.9 \pm 11(20-60)$ & $\begin{array}{l}47.1 \pm 13(17-74) \\
48.3 \pm 14(13-78)\end{array}$ \\
\hline Weight $(\mathrm{kg})$ & $\begin{array}{c}86.1(59-116) \\
66.9(47-97) \\
\end{array}$ & $\begin{array}{l}77 \pm 9 \\
59 \pm 8 \\
\end{array}$ & $121.1 \pm 20(70-194)$ & $\begin{array}{l}129.1 \pm 19(87-201) \\
105.9 \pm 20(66-189) \\
\end{array}$ \\
\hline Stature $(\mathrm{cm})$ & $\begin{array}{l}176.0(164-185) \\
162.0(151-183)\end{array}$ & $\begin{array}{l}176 \pm 7 \\
164 \pm 7\end{array}$ & $167.0 \pm 15(152-182)$ & $\begin{array}{l}171.3 \pm 15(158-188) \\
158.0 \pm 14(141-180)\end{array}$ \\
\hline BMI $\left(\mathrm{kg} / \mathrm{m}^{2}\right)$ & $\begin{array}{l}27.8(22-34) \\
25.5(21-32) \\
\end{array}$ & $\begin{array}{l}25 \pm 2 \\
22 \pm 3\end{array}$ & $43.4 \pm 5(30-58)$ & $\begin{array}{l}44.0 \pm 7(29-71) \\
42.4 \pm 7(28-69) \\
\end{array}$ \\
\hline 6MWD (m) & $\begin{array}{l}576(399-778) \\
494(310-664) \\
\end{array}$ & $\begin{array}{l}593 \pm 57 \\
638 \pm 44 \\
\end{array}$ & $563.6 \pm 62$ & $\begin{array}{l}484.1 \pm 92(40-671) \\
441.9 \pm 90(34-820) \\
\end{array}$ \\
\hline Workload (kg.m) & $\begin{array}{l}49593.6 \\
30298.6 \\
\end{array}$ & $\begin{array}{l}45661.0 \\
37642.0 \\
\end{array}$ & 68251.9 & $\begin{array}{l}57901.4 \\
44774.5 \\
\end{array}$ \\
\hline Clinical characteristic & Healthy & Healthy & $\begin{array}{l}\text { Admitted to a Rehabilitation Unit } \\
\text { devoted to management } \\
\text { of functional and clinical } \\
\text { complications of obesity }\end{array}$ & $\begin{array}{l}\text { Admitted to a Rehabilitation Unit } \\
\text { devoted to management } \\
\text { of functional and clinical } \\
\text { complications of obesity }\end{array}$ \\
\hline
\end{tabular}

Legend: 6MWT: 6 minute walk test; 6MWD: 6 minute walked distance; BMI: body mass index 
Beriault et al. [28] reported that, although BMI is negatively correlated with the distance walked during 6MWT, the actual distance measured in their sample was shorter than in other studies, suggesting that cardiopulmonary fitness of their participants was poorer than in other studies.

In line with these findings, significant correlations were observed between the distance walked during the 6MWT and FEV1 (forced expiratory volume in 1 second), carboxyhemoglobin or minutes walked in the previous week [37].

In addition to the variables mentioned above, linked to clinical and functional impairment, other potential sources of variance may be the different attitudes, beliefs or mood of the participants. In fact, it has been demonstrated that psychological status is related to exercise capacity [52,53].

In order to develop equations with higher predictive capacity, a number of variables, like heart rate, oxygen saturation, blood pressure, muscle strength, and lifestyle, besides the variables previously cited, should be included in the statistical models. Nevertheless, their inclusion in an equation could appear unpractical for clinical use, as most of these parameters are infrequently available in clinical practice [29]. The lack of attention towards these variables leads to a minor precision in the predictive capacity, as shown by $\mathrm{R}^{2}$ values of different equations, rarely higher than $50 \%$.

Most of the published predictive equations show a high variability in their predictive power, not only when applied to obese subjects, confirming that others factors, usually not considered in the performance of the test, could play an important role in the distance walked [54,55]. In a multi-centric study carried out by Casanova et al. [40], despite standardized procedures, similar age and anthropometric variables in the samples enrolled in the 10 centers over 7 countries, the predictive equation developed from the study had an important variability across the centers (R2adjusted: $0.09-0.73$ ) and explained less than $30 \%$ of the variance of the distance walked during the 6MWT in four centers. Additionally, not all variables had a predictive role in each center. The authors stated that there were geographic variations in the distance obtained during the 6MWT that could not be explained by anthropometric factors.

It appears that predictive equations should be validated in the specific population for which they will be used. Studies that have been adopting equations validated on other populations than the experimental one have failed to confirm their validity [56]. The reason for that is likely multifactorial: the standardization procedure used in the test (especially for tests performed before 2002), the track length, the number of tests used for familiarization purposes (there is a learning effect when the test is performed twice, with a mean $15 \%$ improvement in distance walked [18]), the ethnicity, the clinical differences, the anthropometric characteristics (height in particular), and nutritional status must be taken into account [56,57]. Even different speed of habitual walking, cultural and socio-economic aspects related to lifestyle, lack of adequate effort [18] might affect the predicted distance [40].

Finally, all of the equations in the existing literature and reported in our study are unable to explain a variance of the phenomenon higher than 50\%. Most of the differences that we observed between the walked distance and the predicted distance are probably due to this intrinsic error in the equations. Hence, we stress the need to consider parameters involving the clinical, functional, and psychological status, which should be included in the predictive equations for the distance walked during the 6MWT, especially when they have to be applied to particular population subsets, like morbidly obese individuals [44].

Possible limitations of our study are: i) the selection of the equations (see Methods section) derived mainly from healthy, normal weight populations. However, the selected equations are the most frequently used in clinical settings worldwide. The results seem to suggest the need for specific equations in obese subjects and to consider with caution the results obtained from these equations when evaluating individual capacity; ii) the different length of the walkway we used (in this study was $10 \mathrm{~m}$ shorter than the one used by Enright) [58] might have biased the results, although it appears very unlikely, as already commented by other authors [43], that this particular circumstance might have caused such a marked difference in the results. However, it has to be verified whether, turning around and changing direction about 25 times in a six-minute time, particularly in obese subjects where there are higher inertia and biomechanical constraints in rapid movements, would or not affect the performance; iii) a familiarization test was not performed in our sample. The ATS Guidelines for the SixMinute Walk Test state that a practice test is not needed in clinical settings although it should be considered. In fact, the six-minute walked distance is only slightly higher for a second 6MWT performed a day later and the mean reported increase ranges from 0 to 17\% [23]. In our study, the day before the 6MWT, an exhaustive explanation of the procedures, including where the test would take place, was provided to the patients in order to make the test more reliable (by improving coordination, finding optimal stride length, and overcoming anxiety [23]),

In conclusion, the distance walked during the 6MWT by obese subjects does not appear to be only influenced by age, gender, BMI and body weight and height, as suggested by most of the equations available in the literature. The present study raises criticisms on the accurate prediction capacity of the available equations on 6MWT results in obese subjects. Bearing in mind that the main objective of the test in obese subjects undergoing nutritional rehabilitation is to assess functional capacity, and plan and monitor interventions, future research should be designed and performed in order to develop and validate populationspecific equations, by including variables related to clinical, functional, and psychological areas usually impaired in obese individuals.

\section{References}

1. Donini LM, Cuzzolaro M, Spera G, et al. Obesity and eating disorders. Indications for the different levels of care. An italian expert consensus document. Eat Weiting Disord 2010;15:1-31.

2. Donini LM, Spera G, Cuzzolaro M, Rosano A. Percorso riabilitativo metabolico-psico-nutrizionale nel trattamento dell'obesità. Rapporto Osservasalute 2009. Rome: Osservatorio nazionale sulla salute nelle regioni italiane; 2009.

3. Visser M, Kritchevsky SB, Goodpaster BH, et al. Leg muscle mass and composition in relation to lower extremity performance in men and women aged 70 to 79: the health, aging and body composition study. J Am Geriatr Soc 2002;50:897-904.

4. Lean ME, Han TS, Seidell JC. Impairment of health and quality of life in people with large waist circumference. Lancet 1998;351:853-6.

5. Han TS, Tijhuis MA, Lean ME, Seidell JC. Quality of life in relation to overweight and body fat distribution. Am J Public Health 1998;88:1814-20.

6. Agusti AG, Noguera A, Sauleda J, et al. Systemic effects of chronic obstructive pulmonary disease. Eur Respir J 2003;21:347-60.

7. Ochs-Balcom HM, Grant BJ, Muti P, et al. Pulmonary function and abdominal adiposity in the general population. Chest 2006;129:853-62.

8. Atwood CW. Sleep-related hypoventilation. Chest 2005;128:1079-81.

9. Mutlu GM, Rubinstein I. The saga of obstructive sleep apnea sindrome and daytime hypercapnia. Chest 2005;127:698-9.

10. Evers Larsson U, Mattsson E. Functional limitations linked to high body mass index, age and current pain in obese women. Int $\mathrm{J}$ Obes Relat Metab Disord 2001;25:893-9.

11. Ferraro KF, Su YP, Gretebeck RJ, et al. Body mass index and disability in adulthood: a 20-year panel study. Am J Public Health 2002;92:834-40.

12. Ranavolo A, Donini LM, Mari S, et al. Lower-limb joint coordination pattern in obese subjects. Biomed Res Int 2013;2013:142323. 
13. Todd Cade W. Diabetes-related microvascular and macrovascular diseases in the physical therapy setting. Phys Ther 2008;88:1322-35.

14. Belfer MH, Reardon JZ. Improving exercise tolerance and quality of life in patients with chronic obstructive pulmonary disease. J Am Osteopath Assoc 2009;109:268-78.

15. Myers J, Prakash M, Froelicher V, et al. Exercise capacity and mortality among men referred for exercise testing. $\mathrm{N}$ Engl $\mathrm{J}$ Med 2002;346:793-801.

16. Hamilton AL, Killian KJ, Summers E, Jones NL. Muscle strength, symptom intensity, and exercise capacity in patients with cardiorespiratory disorders. Am J Resp Crit Care Med 1995;152:2021-31.

17. Killian KJ, Leblanc P, Martin DH, et al. Exercise capacity and ventilatory, circulatory, and symptom limitation in patients with chronic airflow limitation. Am Rev Respir Dis 1992;146:935-40.

18. Enright PL, Sherrill DL. Reference equations for the six-minute walk in healthy adults. Am J Respir Crit Care Med 1998;158:1384-7.

19. Rocha Moreira FB, De Lucena Panka GF, Rocha Vieira DS, et al. Functional evaluation instruments in patient with chronic obstructive pulmonary disease: a review of the literature. Jour Resp Cardiov Phy Ther 2012;1:59-66.

20. Enright PL. The six minute walk test. Respir Care 2003;48:783-5.

21. Reybrouk T. Clinical usefulness and limitation of the 6-minutre walk test in patients with cardiovascular or pulmonary disease. Chest 2003;23:325-7.

22. Poole-Wilson PA. The six-minute walk: a simple test with clinical application. Eur Heart J 1999;21:507-8.

23. American Thoracic Society Statement. Guidelines for the sixminute walk test. Am J Respir Crit Care Med 2002;166:111-7.

24. Miyamoto S, Nagaya N, Satoh T, et al. Clinical correlates and prognostic significance of the six-minute walk test in patients with primary pulmonary hypertension. Am J Respir Crit Care Med 2000;161:487-92.

25. Gibbons WJ, Fruchter N, Sloan S, Levy RD. Reference values for a multiple repetition 6-minute walk test in healthy adults older than 20 years. J Cardiopulm Rehabil 2001;21:87-93.

26. Troosters T, Gosselink R, Decramer M. Six minute walking distance in healthy elderly subjects. Eur Respir J 1999;14:270-4.

27. Steffen TM, Hacker TA, Mollinger L. Age- and gender-related test performance in community-dwelling elderly people: six-minute walk test, Berg balance scale, timed up and go test, and gait speeds. Phys Ther 2002;82:128-37.

28. Beriault K, Carpentier AC, Gagnon C, et al. Reproducibility of the 6minute walk test in obese adults. Int J Sports Med 2009;30:725-7.

29. Capodaglio P, De Souza SA, Parisio C, et al. Reference values for the 6-min walking test in obese subjects. Disabil Rehabil 2013;35:1199-203.

30. Hulens M,Vansant G, Claessens AL, et al. Predictors of 6-minute walk test results in lean, obese and morbidly obese womwn. Scand Med Sci Sport 2003;13:98-105.

31. Larsson UV, Keynisdottir S. The six-minute walk test in outpatients with obesity: reproducibility and known group validity. Physioter Res Int 2008;13:84-93.

32. Lohman TG. Manuale di riferimento per la standardizzazione antropometrica. Milano. EDRA; 1992.

33. Borg G. Psychophysical scaling with applications in physical work and the perception of exertion. Scand J Work Environ Health 1990;16:55-8.

34. Chetta A, Zanini A, Pisi G. Reference values for the 6-min walk test in healthy subjects 20-50 years old. Respir Med 2006;100:1573-8.

35. Alameri H, Al-Majed S, Al-Howaikan A. Six-minute walk test in a healthy adult arab population. Respir Med 2009;103:1041-6.

36. Ben Saad H, Prefaut C, Tabka Z, et al. 6-minute walk distance in healthy north africans older than 40 years: influence of parity. Respir Med 2009;103:74-84.

37. Camarri B, Eastwood PR, Cecins NM, et al. Six minute walk distance in healthy subjects aged 55-75 years. Respir Med 2006;100:658-65.

38. Iwama AM, Andrade GN, Shima P, et al. The six-minute walk test and body weight-walk distance product in healthy brazilian subjects. Braz J Med Biol Res 2009;42:1080-5.

39. Poh H, Eastwood PR, Cecins NM, et al. Six-minute walk distance in healthy singaporean adults cannot be predicted using reference equations derived from caucasian populations. Respirology 2006;11:211-6.

40. Casanova C, Celli BR, Barria P, et al. Six Minute Walk Distance Project (ALAT). The 6-min walk distance in healthy subjects: reference standards from seven countries. Eur Respir J 2011;37:150-6.

41. Masmoudi K, Aouicha MS, Fki H, et al. The six-minute walk test: which predictive values to apply for tunisian subjects aged between 40 and 80 years? Tunis Med 2008;86:20-6.

42. Moher D, Liberati A, Tetzlaff J, et al. Preferred reporting items for systematic reviews and meta-analyses: the PRISMA statement. PLoS Med 2009;6:e1000097.

43. Jenkins KR. Obesity's effects on the onset of functional impairment among older adults. Gerontologist 2004;44:206-16.

44. Donini LM, Poggiogalle E, Mosca V, et al. Disability affects the 6minute walking distance in obese subjects (BMI $>40 \mathrm{~kg} / \mathrm{m}^{2}$ ). PLoS One 2013;8:e75491.

45. Salvadori A, Fanari P, Mazza P, et al. Work capacity and cardiopulmonary adaptation of the obese subject during exercise testing. Chest 1992;101:674-9.

46. Salvadori A, Fanari P, Fontana M, et al. Oxygen uptake and cardiac performance in obese and normal subjects during exercise. Respiration 1999;66:25-33.

47. Malatesta D, Vismara L, Menegoni F, et al. Mechanical external work and recovery at preferred walking speed in obese subjects. Med Sci Sports Exerc 2009;41:426-34.

48. Capodaglio P, Vismara L, Menegoni F, et al. Strength characterization of knee flexor and extensor muscles in Prader-Willi and obese patients. BMC Musculoskelet Disord 2009;10:47.

49. Wearing SC, Hennig EM, Byrne NM, et al. Musculoskeletal disorders associated with obesity: a biomechanical perspective. Obes Rev 2006;7:239-50.

50. Wearing SC, Hennig EM, Byrne NM, et al. The biomechanics of restricted movement in adult obesity. Obes Rev 2006;7:13-24.

51. Capodaglio P, Castelnuovo G, Brunani A, et al. Functional limitations and occupational issues in obesity: a review. Int J Occup Saf Ergon 2010;16:507-23.

52. King B, Cotes JE. Relation of lung function and exercise capacity to mood and attitudes to health. Thorax 1989;44:402-9.

53. Morgan AD, Peck DF, Buchanan DR, McHardy GJR. Effect of attitudes \& belief on exercise tolerance in chronic bronchitis. Br Med J 1983;286:171-3.

54. Cote CG, Casanova C, Marín JM, et al. Validation and comparison of reference equations for the six-minute walk test. Eur Respir J 2008;31:571-8.

55. Lord SR, Menz HB, Pod B. Physiologic, psychologic, and health predictors of 6 -minute walk performance in older people. Arch Phys Med Rehabil 2002;83:907-11.

56. Dourado VZ. Reference equations for the 6-minute walk test in healthy individuals. Arq Bras Cardiol 2011. [Epub ahead of print]

57. Lung function testing: selection of reference values and interpretative strategies. American Thoracic Society. Am Rev Respir Dis 1991;144:1202-18.

58. Enright PL, McBurnie MA, Bittner V, et al. The 6-min walk test: a quick measure of functional status in elderly adults. Chest 2003;123:387-98. 